\title{
BRITAIN AND CONSENSUS POLITICS, 1945-1955: MYTH OR REALITY?
}

\author{
Carlos Soriano-Jiménez, Independent Scholar \\ Email: Carlos52004@hotmail.es
}

Received: April 1, 2021

Accepted: September 15, 2021

\begin{abstract}
This study lies within the framework of the years 1945-1955, which correspond to Clement Attlee's Labourite and Winston Churchill's Conservative administrations. The objective is to demonstrate, by means of an analysis of their speeches and the proposals of their respective political parties, that the ideological differences hindered a total agreement. These primary sources are examined from several perspectives. The main emphasis of this study falls on the ideology as a distinctive element and its influence on other fields such as education, the welfare system or the economy. The results reveal a lack of consensus based on their opposite political cultures.

Keywords: Attlee, Churchill, Speeches, Consensus, Ideology, Labour, Conservative.

Resumen: Este trabajo de investigación se enmarca en el período comprendido entre 1945 y 1955, que se corresponde con las administraciones del laborista Clement Attlee y del conservador Winston Churchill. El objetivo es demostrar, mediante un análisis de sus discursos y las propuestas de sus respectivos partidos políticos, que las diferencias ideológicas impidieron un acuerdo total. Se abordan estas fuentes primarias desde varias perspectivas, teniendo como eje principal la ideología como elemento diferenciador y su repercusión en ámbitos como la educación, el estado del bienestar o la economía. Los resultados revelan una falta de consenso proveniente de culturas políticas opuestas. Palabras clave: Attlee, Churchill, Discursos, Consenso, Ideología, Laborista, Conservador.
\end{abstract}

\section{INTRODUCTION}

The year 1945 was one of the most crucial moments in British history. It was the year of victory. The country emerged triumphant from World War II and the Labour Party won a landslide victory in the national elections. It was the new beginning of peace and new political and economic changes.

By the 1970s, historians began to assess the transformations that had occurred until then. Since 1945, two political parties, the Conservatives and the Labour Party had shared the political power. The belief of the existence of a post-war consensus during the 1940s 
and 1950s based, for instance, on the existence of a mixed economy, the welfare system and extensive nationalization, was a thesis proposed by some historians, the consensualists, and refuted by others, the anti-consensualists. This study aims to consider and analyze both sides of this debate and to provide a clear argumentation of whether there was political and ideological consensus or not.

In order to provide a definition of "consensus" based on ideological grounds and to prove its existence, Dean Blackburn argues that the epistemology that rested behind the two ideological currents, "Middle Way Conservatism"1 and "Revisionist Socialist Democracy"2 (of the Conservative and Labour Party respectively), led to continuity, that is, to "acknowledge the positive contributions that their opponents had made to public policy" (2017: 203). Unilateralism and dogmatism were vetoed by both political factions as they were in favour of a constructive opposition. According to Blackburn, Middle Way Conservatism and revisionists preferred to avoid referring utopian views which were not related to their understandings of human reason (2017: 204-205).

In the realm of politics, according to Keith Lehrer and Carl Wagner, governments have frequently relied on the principle of rational consensus which "commits men to accept some form of government" (1981:3) in order to justify or legitimize their rule. Rational consensus, in turn, as its name implies, is based on a commonly shared principle of reason. It can be argued that, in the 1940s, these principles were expounded in the Beveridge Report ${ }^{3}$, which stated that the government should fight against unemployment, poverty, illiteracy, disease and lack of housing. Following the reasoning of Lehrer and Wagner, consensualists believe that due to the fact that there was a rational basis for accepting these principles, consensus was rational. But, even if there was a common agreement among British citizens over the idea that the government should take an active role in this fight, it is questionable whether the British society and politicians agreed on the means to achieve it.

According to Dennis Kavanagh, defining "consensus" has been troublesome. He discusses some usages of the term "consensus" referring to the post-war policy agenda: to apply to ends, "negative consensus" and "relative consensus" (1992: 177). Firstly, Kavanagh readily accepts that there was consensus based on the basic principles: "shared assumptions and expectations among the front-benchers" (1992: 177), that is, those policies which were the only ones that could be "administratively practicable, economically affordable, and politically acceptable" (1992: 177). Secondly, "negative consensus" is a term employed to define "what was excluded from the policy agenda" (1992: 177) of the two main political parties, such as the rejection of "free market policies for the NHS" (1992: 178). Finally,

1 "Middle Way Conservatism" was more effectively pursued by young conservatives such as Macmillan, who were interested in trying to amalgamate capitalism and equality (Blackburn 2017: 197).

2 "Revisionist Social Democracy", on the other hand, was the result of the critique of rigid Marxism. According to this reasoning, no extensive nationalization was essential for egalitarianism and excessive taxation would lead to an ineffective economy (Blackburn 2017: 198).

3 It was a government report published in 1942 which proposed to address the most pressing problems of British society at the time.

4 Spokespeople who sit in the front row in Westminster Parliament and are trustworthy supporters of the main political party policies. 
"relative consensus" is a study of this agreement compared to other countries and other historical periods. Richard Toye had already argued that there was a similar political and economic agreement in the USA (2013: 7) but Kavanagh believes that it existed in other countries in Western Europe (1992: 178).

Toye questions himself how to frame "consensus" as an abstract concept and in what terms it should be done - was it simply the product of rhetorical language or did it include real areas of common agreement - such as economy and the welfare state? The bipartisan nature and discourse of British politics has often distorted the image of consensus (2013: 7). In the 1940s and 1950s the Labour party, according to Toye, viewed "consensus" rather negatively, as they wanted a radical shift which would no longer be under the control of the political establishment. For the Conservative party, "consensus" was synonymous for the abolition of the most radical aspects of the Labour programme, as noted in Churchill's reluctance to implement the reforms proposed by the 1942 Beveridge Report during the coalition government (2013: 9). The idea of a "common ground", was, of course, reshaped and rebranded for the specific purposes of the different political parties. During Attlee's government, the term "middle way" was most commonly used, with the evident connotations of "catering" for the needs of the middle class. Toye points out that those that stood outside consensus were the Liberal Party, who eschewed this notion of "middle way" because both the Labourites and the Conservatives considered themselves representatives of it (2013: 15).

The hypothesis proposed in this study is that there was not full consensus between the Conservative and the Labour political parties. Circumscribing the analysis only to their policies might be completely superficial. The main issue that caused disagreement was their contradictory ideologies. This is explained by the fact that they belonged to different political cultures. The Labour roots came from the Social democracy ${ }^{5}$, whereas the Conservatives in the 1950 s adhered to the principles of Tory democracy ${ }^{6}$. Even if their policies were similar, their approaches to tackle specific topics diverged.

\section{HISTORICAL FRAMEWORK}

The historical context which frames the period studied here (1945-1955, the administrations of Clement Attlee and Winston Churchill) in the international stage is one of a great power which has recently been on the verge of collapse and, in words of Geoff Stewart, it was now a "moth-eaten one" (2010: 36). Even though the present research is concerned with domestic policies within the United Kingdom, it is practically impossible to view them without the wider scope of foreign politics. Indeed, it can be argued that the first seeds of domestic consensus (if it existed at all) were sown during World War II. Neville Chamberlain's 7 response to the German war machinery was lukewarm and he was replaced by well-known Churchill as Prime Minister in 1940. In the following years, the United

5 One of the types of Socialism. It endeavors to achieve a gradual political and economic reform towards social justice within the scaffold of liberal democracy and the capitalist economy.

6 Also known as one-nation conservatism, it is a political philosophy under the umbrella of conservatism, which was predominant in the 1950s and 1960s in Great Britain.

7 Conservative Prime Minister of the United Kingdom (1937-1940). 
Kingdom was able to revert its fortunes. Indeed, the outcome was a moral and military victory, but it evinced the decline of the Empire. As a consequence, British politicians' mentalities were deeply shaped by the nature of the war and its devastating consequences. The extent to which they agreed on how to reconstruct Britain is interpretable, but it is outstandingly clear that foreign policy had had and would have a direct influence in the policies in the domestic realm.

The most direct example of how this was materialized was the wartime coalition (19401945). In the darkest hour, King George VI appointed Churchill as Prime Minister (PM). He included in his war cabinet prominent figures from all political parties. This willingness to unite totally divergent opinions into a single government had created some sense of comradeship. The British Union of Fascists, under the leadership of Oswald Mosley, was rejected for obvious reasons and the Communist Party only supported the government once the USSR entered World War II. Yet the political scope of the coalition was huge, as it included the majority of political parties from centre-left and centre-right. Young members of parliament (MPs) from both sides had fought in the army and senior politicians had collaborated hand in hand in the war effort (Stewart 2010: 12). All this evidence could be interpreted as one of the signs of political consensus before 1945, at least on the personal level, but it must be taken into account that it only existed in exceptional circumstances.

The coalition ended once Germany surrendered and the United Kingdom returned to the petty political rivalry. Was this a sign of division and change within the United Kingdom? In the July elections, the Labour candidate Clement Attlee achieved a resounding electoral success. The first question that should be considered in relation to this study is whether his policies were maintained after he stepped out of Number 10 or whether they were reverted when Churchill returned back to power.

Attlee laid the foundations for a mixed economy. Firstly, he developed the welfare state. The extent of whether it was a breakthrough or a gradual process of continuity is open to debate. The Liberal government had implemented previously a national insurance for sickness and unemployment in 1911 and pensions already existed. Yet the Labour reforms (the National Insurance Act 1946 and the National Assistance Act 1948) were now universal for all. The creation of the National Health Service (NHS) in 1946 was another ever-lasting reform which had not hitherto been implemented on such a scale before.

A mixed economy also meant some considerable degree of control of the state over the economy. Clause IV in the 1918 Labour constitution defined nationalization as one of its primary objectives. Were the roots of the existing economic system actually threatened or was it a controlled step towards a more "social" capitalism?

Churchill's supposed conciliatory disposition towards the Labour reforms under his last administration is another question which determined the existence of compromise between the two political parties. Housing became a primary objective and the power of the trade unions was respected. Tory democracy became the philosophical cornerstone of the modern conservatism. However, income and purchase tax cuts in the Butler's ${ }^{8} 1955$ budget show that the Conservative party could be also prone to reduce the burden of taxation of the Labour administration whenever possible (Stewart 2010: 62).

8 Conservative Chancellor of the Exchequer (1951-1955). 
Finally, central to this study is the nature of the Labour and Conservatives when they were in the opposition. Churchill managed to maintain a firm grip of the Conservative party during 1945-1951, yet sometimes his political views were considered too old-fashioned by his peers. By 1951 onwards, disaffection grew in Labour Party. Left-wingers, the Bevanites ${ }^{9}$, seemed to challenge the supposed post-war consensus, but what was really their political strength?

\section{LITERATURE REVIEW: A HISTORICAL OVERVIEW OF POST-WAR POLITICAL CONSENSUS IN BRITAIN, 1945-1955}

A historical overview on consensualist and non-consensualist views of British politics shows the widespread academic acceptance that there were both agreements and significant divergences on key issues. The paragraphs below present these different viewpoints. They provide a general picture of the research done so far in the domestic issues that arouse at the time and serve as a clear guideline of the topics that should be examined when proving the validity of the thesis proposed.

\subsection{Consensualists}

There has been some considerable debate about whether there was political consensus during 1945-1955 and in what terms. Paul Addison's study The Road to 1945 (1975: 14) shed some light to this historiographical debate and dominated literature for a large period of time. His contribution to the discussion revolves around a researched argument which suggests that it was Churchill's coalition government which, in Richard Toye's words, "established the groundwork" (2013: 5) of the consensus. Many historians have followed his interpretation (most clearly Dennis Kavanagh, Peter Morris, Derrick Murphy and Geoff Stewart). For Murphy, consensus was "built around a shared belief in Keynesian" economics, the welfare and the mixed economy" (2004: 291). For Stewart, "much of the conflict was simply ritual" (2010: 20). In the following paragraphs there will be presented pieces of evidence for each of the two historical interpretations.

Brian Harrison defends that after the electoral defeat of 1945, the Conservative party moved towards the centre in the political spectrum (1999: 304). Trade unions were no longer seen as enemies and the reduction of unemployment was deemed as a necessary step for the post-war reconstruction (Murphy 2004: 312). For Kenneth O. Morgan, Churchill's attitude was one of cautious reconciliation. His restless desire was one of social cohesion and not of confrontation. As far as labour conditions are concerned, Stewart states that Churchill "was anxious to avoid the impression of union bashing" (2010: 56) and he did not employ troops against strikers, unlike Attlee (2010: 57). This opinion is also corroborated by Harrison

9 Supporters of Aneurin Bevan. He was the major Labour Minister of Health during Attlee's ministry and he was also Minister of Labour and National Service (1951).

10 Keynesian economics refers to the macroeconomic theories presented by the economist John Maynard Keynes. They were established, to a varying degree, in most developed nations in the 1930s amid the Great Depression. 
(1999: 304). "Paternalistic" figures in the cabinet like Macmillan ${ }^{11}$, R.A. Butler and Eden ${ }^{12}$ were all at the forefront of this ethos (Morgan 1990: 113). The repeal of the 1906 Trade Disputes Act, which pleased the T.U.C ${ }^{13}$, and the lenient outlook towards railway strikes in 1954 exemplified this "transformation."

Arguably, taking over $20 \%$ of the economy might have seemed at the time quite revolutionary, but Murphy argues quite the opposite: the nationalized companies "turned out to be ... conservatively run" (2004: 289) as the previous managers were kept in office. There were no further inroads made towards cooperatives. Those nationalized companies were already controlled to some degree by the government previously. Compensations were generally generous and/or the government intervened when the private company was on the verge of bankruptcy. Morgan concludes that Attlee's major reforms, such as nationalization, were carried out with "little controversy" (1990: 33) and "without tears" (1990: 36). Robert Blake, an anti-consensualist, acknowledges that nationalization was not polemical (1985: 316) but he believes that the Conservatives accepted it because of electoral pragmatism, as indicated by Toye (2013: 12) and Harrison (1999: 314).

\subsection{Anti-consensualists}

Revisionist Ben Pimlott has attacked the consensualists by stating that consensus is a concept promoted by those who felt "nostalgia" (1994: 238) when it was really a historical period of bitter political division. Ian Cawood partially subscribes to the thesis that the Conservative party did not consider themselves as part of the political consensus, quite the opposite. It is inferred, through Cawood's lines, that true consensus lay only in the Conservative opposition and later its government: the acceptance of the Labour reforms, but also ending rationing, extra house building and less bureaucracy (2004: 250).

Morgan (and also Cawood 2004: 248) underlines that, ironically, those who were more critical to the reforms was the far-left labour party faction, concretely the backbenchers ${ }^{14}$. They insisted that the managers of the nationalized businesses were still not accountable to the workers (1990: 35). They also considered the building house programme insufficient and there were instances of squatters breaking into houses (1990: 40). In addition, Ellen Wilkinson's ${ }^{15}$ implementation of the Butler Act of 1944 in education brought hostility from the far-left again as the grammar schools continued to be the refuge of the elite class (1990: 41). Bevan's resignation in 1951, in Morgan's words, marked "a notable divide in post-war politics" (1990: 103) and sectionalism. Extremism appeared to gain more and more support, for example, in the National Executive Committee ${ }^{16}$ (1990: 61). These are pivotal pieces of evidence that show that consensus was not totally widespread. Stewart, a

11 Minister of Housing during Churchill's administration.

12 Conservative Foreign Secretary (1951-1955).

13 Trade Union Congress, a federation of trade unions of England and Wales.

14 A Member of Parliament who does not hold any official position.

15 Minister of Education under Attlee's administration (1945-1947) and suffragist.

16 The National Executive Committee ensures that the Labour party objectives are fulfilled. 
generally consensualist historian, admits that overall, 1951-1955 was a period of general peace and tranquillity, but surely not in the Labour ranks, which continued to experience internal division brewing between "Bevanites" and "Gaitskellites"17 (2010: 64). For Harrison there are significant difficulties for taking the consensualist view. Dissension still existed: the "fundamentalist left" (1999: 315) of the Labour party considered "consensus" as an inevitable step for a fully-fledged socialist state. Consensualist historians have generally neglected the internal divisions within the Labour party.

\subsection{British Society and Consensus}

Toye believes that we should not assess "consensus" from a retrospective perspective and considers just as important what British society thought about "consensus" at the time (2013: 3). As stated by Murphy, the Beveridge Report was one of the crucial elements of post-war consensus. 86\% of the population were in favour of the report (2004: 282). Books and pamphlets about the post-war reconstruction written by members of the 1941 Committee $^{18}$ and which shared progressive values sold exceptionally well. One example was "A Plan for Britain" 19 . Famous economists and experts of all fields outlined their proposals: the creation of a National Health Service $\left(\right.$ Owen $^{20} 1941$ : 14-15), the demolition of run-down neighbourhoods (Fry ${ }^{21}$ 1941: 16-20), a mixed economy and full employment (Balogh 22 1941: 10-13). This issue generated much interest and the offices of Picture Post received "more than 2,000 letters", most of them being "enthusiastic" (Todman 2016: 642). Attlee's reforms, many of them inspired by these proposals, proved to be far more consensual among the British society than in the House of Commons.

Unser Kampf, written by J. B. Priestly's ${ }^{23}$ friend, Sir Richard Acland ${ }^{24}$ (another member of the 1941 Committee), also laid the groundwork for the social consensus. Acland preached about the creation of a new post-war morality. His words stroke a chord with both many religious and British workers: "We have failed because of our selfishness, and we need a new standard of morality" (1940: 31). Unser Kampf, which, unlike Mein Kampf, placed strong emphasis on egalitarian values (notice the difference between "our struggle" and "my struggle"), became a best-seller (Todman 2016: 644, emphasis added). By 1945, "Britain emerged ... with a strong tide of collectivist fervour running in favour of building

17 Supporters of the political right-wing faction of the Labour Party.

18 The 1941 Committee was a progressive and liberal organization which discussed about how post-war Britain should be governed.

19 An issue published in 1941 in Picture Post, a photojournalistic magazine.

20 Assistant Secretary-General for Economic Affairs in the United Nations.

21 British architect and painter.

22 British economist, fervent defender of nationalization.

23 British social commentator and novelist. He was author of the popular left-wing political work Out of the People written in 1941, which called for the creation of a welfare state.

24 Member of the socialist Common Wealth Party. 
... a New Jerusalem" (Stevenson 1991: 89). Individualism and the deference for the elite had slowly been eroded.

The living conditions of the working class seemed to have improved considerably. A plumber who was interviewed in 1951 expressed his impressions in the following manner: "There is so much work to be done and so little unemployment so if the boss rattles at you or threatens you with the sack you can just up and leave ... The working people are better off and the bosses have lost the grip" (plumber, personal communication, 1951, as cited in Marwick 2003: 23-24).

A strong sense of pride, which emerged after the suffering from the war, demonstrated that there had been a mood swing. For Marwick (2003: 20), who has devoted much of his work to post-war British society, class-consciousness was affected by the war and the Labour government. Class boundaries became, according to him, more blurred. Stephen Brooke corroborates this viewpoint. He states that during the 1950 s, affluence and "prosperity may have worn away the singularity and the coherence of the working class identity" (2001: 773).

For the average citizen, once Attlee's reforms got underway, they seemed to be well received, as if they were their own right. This is at least as Andrew Marr depicts it: "There are many moving accounts of the queues of unwell and impoverished people surging forward for treatment in the early days of the NHS, arriving in hospitals and doctors' waiting rooms for the first time not as beggars but as citizens with a sense of right" (2007: 67, emphasis added).

However, not all historians argue that Attlee's reforms were perceived in the same way. Morgan, who devotes much of his work to this issue, states that the general "mood" during Attlee's ministry during 1945-1947 was "one of welfare and the public ethic" (1990: 41), but since 1947, consensus crumbled. Marr also acknowledges that there was still much continuity in British society during 1945-1955: "the ruling class was still the ruling class" (2007: 45). Blake contends that, for the general public, Attlee's ministry caused bitter resentment and division. The middle-class was "disenchanted" (1985: 315) and the upper classes were unwilling to allow "a new world of high wages, full employment" (1985: 315).

The government was attacked from the left and the right. Society became more polarized. The "sharpness of the division was unusual" (Morgan 1990: 63), as the right "re-armed" itself too with the creation of nostalgic middle-class pressure groups who would undermine the Labour government. Stewart agrees with Morgan in the sense that since 1947 consensus was falling rapidly. Rationing had alienated the middle classes, and the "mood of the country became almost rebellious" (2010: 41). It was, according to Cawood, reviled in comedy shows and in middle-class pressure groups (2004: 249). Morgan concludes that "two nations were clearly emerging in England" (1990: 85) and that the 1951 elections were one of the most disputed ones up to 1979. Pimlott also clarifies that the results of the elections do not reflect consensus but an electorate "sandbagged in their electoral trenches ... anonymous infantry of two implacably opposed armies" (Pimlott, Kavanagh and Morris 1989: 13).

Assuming that the relationship between gender ideology and class identity exists, Stephen Brooke asks us to consider whether gender was "present at the (apparent) death" (2001: 774) of class identification. His study provides a comprehensive analysis of how several books written during the 1950s, such as Myrdal and Klein's study of the increasingly important role of women at work in a two-phased revolution in Women's Two Roles (1956: 
1), reflected this relationship change. Brooke points out several factors which support his statement: for example, the increase in the female labour in the 1950s (2001: 778) and shifting attitudes towards maternity and birth control (2001: 782). These changes "had inscribed the category of working class feminity and maternity with new experiences and expectations, such as work in the public sphere" (2001: 783).

However, other recent historians have undervalued the impact of these changes and believe that women's and government's perceptions towards the state of women in the workplace were not dramatically transformed. Even if Attlee's legislation was one of the first steps towards equality, it often fell behind in his list of priorities of domestic policy, both in timing and in expenditure. Both Conservative and Labour political manifestos pledged to introduce equal pay ("This is the Road" 1950: no pages; "Let Us Win Together" 1950: no pages). Even though this might be perceived as a radical departure from the previous election manifestos, which had not made any specific references to gender equality whatsoever, the impact of this reform was very limited. Despite the fact that "the principle of equal pay commanded widespread support" (Pugh 2000: 298), the feminist movement was hindered by middle-class women, who, once they achieved equal pay for civil servants and teachers, made no further inroads into private employment. As a result, in terms of equal pay, "triumph ... does not seem to have been used to raise the general profile of the women's movement” (Pugh 2000: 301).

By the 1940s, many Labour women wanted to no longer be associated with the previous struggle of feminism mainly advocated by "single working women, especially middle-class and professional women” (Tomlinson 1997: 208). During the 1940s, the Ministry of Labour policy and propaganda placed emphasis on the temporary nature of those jobs which had been taken by women during the war and which were previously only accessible to men (Tomlinson 1997: 191). Many wartime nurseries were closed down (Pugh 2000: 286). The Family Allowances Act of 1945 and the National Institute of Houseworks favoured natalism and supported the working-class women at home. The evidence from the surveys of the Mass Observation Archive and the British Institute of Public Opinion indicates that "the post-war aspirations of the vast majority of women and factory workers were focused on marriage and domestic life" (Smith 1986: 218). Similarly, for Tomlinson, "early post-war surveys suggested that women had a fairly pragmatic attitude to work, rather than one driven by very strong notions of a 'woman's place"' (1997: 192). In sum, considering the attitudes of women and employers towards work, some historians have underestimated the significance and the scope of some social changes towards gender equality at work in the 1950s.

\section{AN ANALYSIS OF POST-WAR CONSENSUS THROUGH PRIMARY SOURCES}

The next part of the study attempts to answer to the question proposed in the introduction and it contributes to the existing research of this debate. For that purpose, the 1945 and 1950 Labour and Conservative Party electoral manifestos and some of Churchill's and Attlee's speeches during that period will be extensively compared and contrasted. The full list can be found in the appendix below. 
One of the limitations of the analysis of these primary sources is that they do not generally tend to reflect completely the political positions held by the different factions within each of the political parties referred previously in this study. It is worthy of comment that, for example, in some cases, Churchill's views did not mirror entirely the "official" political position expressed in the Conservative political manifestos. The generational gap between him and the younger generations within the political party, who in words of Stewart, were climbing "the greasy pole" (2010: 56), was noteworthy: generally speaking, Churchill's political beliefs tended to be more right-wing compared to the rest. The opposite problem occurred in the Labour party. Attlee's control of the party was never complete and the discontented Bevan and Harold Wilson ${ }^{25}$, altogether with those who sided with him, pressed for a much more socialist programme. As a result, it is found that sometimes, the political discourse employed by these political actors was far more radical than the actual measures that they implemented.

A balanced judgement is only reached based on assessing the interaction between the rhetorics and the actual laws of those politicians who implemented them. Churchill's ideas were well respected in the Conservative Party, so his speeches serve as a reliable source for the diagnosis of the political climate during the time. Attlee's speeches and proposals also showed the current state of affairs, as they attempted to bring to the forefront the social inequalities he vividly experienced in the London East End district. Overall, the most of the selected primary sources are suitable for the investigation as they mention measures and policies that really would have an impact in post-war Britain. The division of this analysis is twofold: the first section examines broadly the ideological theories that set these two political organizations apart, whereas the last sections show how ideology had an influence on the conduct of the economy and social matters.

\subsection{Ideology}

\subsubsection{Property-owning Democracy}

On this first issue, Churchill's speeches unmistakably presented the ideological differences between the Conservative and Labour Party; he particularly paid attention to the concept of property-owning democracy ${ }^{26}$ referred by him one year after his electoral defeat (2013: 359) and later consolidated in the 1950 Conservative manifesto "This is the Road". Churchill referred to the possibility that the employees could become involved in the profit of a business by means of shares (2013: 360). He intended to create a social system in which individuals could participate in the market as a means for social advancement. This philosophical tenet became the hallmark of the Conservative party during the 1980s. This idea was not new in the Conservative party, but he presented it in a moment in which nationalization was popular and swept most of Conservative opposition. However, we

25 President of the Board of Trade (1947-1951) and later, Prime Minister during 1964-1970 and 1974-1976.

26 In its wider sense, it refers to an economic system in which the main aim is the extension of the distribution of property to all the social groups. 
must not exaggerate the significance of his words either. The Labour party was not really interested in creating a corporativist society. The state intervention in the economic market did not mean that the employees had now a direct control over the newly industrialized industries. So, in practice, the idea of property-owning democracy was really reduced to the possibility that everyone possessed their house, as expressed succinctly in the 1950 Conservative manifesto ("This is the Road" 1950: no pages).

Churchill defended that British tenants should have the right to purchase from the local authorities (2013: 373). This would be later manifested in the 1980 Housing Act. Attlee encouraged quite the opposite. The creation of council houses, public rented accommodation in the New Towns Act of $1946^{27}$ and the Town and Country Planning Act of $1947^{28}$ were two measures in a totally different direction. The final objective was that people from all social classes lived in the same type of residence, which would hopefully erase class differences. The 1945 Labour manifesto also aimed to ensure price controls ("Let Us Face the Future" 1945: no pages), which was quite different to the deregulation of the housing market proposed by the Conservatives. So, in a sense, this reinforces the idea that Churchill can be regarded not as a consensualist politician, but rather as a precursor of the hard-line Thatcherian politics.

Even though on the surface the debate centered on the right to buy private housing, the underlying debate had ideological undertones: it was a struggle between individualism and collectivism. Attlee lightly touched on this historical and political struggle when he addressed the parliament in the second reading of the National Insurance Bill in 1946, but his pungent criticism towards individualism explains why collectivism as a moral value would be the essence of the Labour reforms, both in terms of nationalization and also, going back to the topic dealt here, housing: "the ill-regulated and insufficient efforts of individuals" (1946: 92) should be replaced by the "collective security" (1946: 92). The subject of property-owning democracy and housing thereby became a conflict in the domains of ideological discourse.

\subsubsection{Economic Prosperity and Even Distribution of Wealth}

Wealth inequality and its causes was another area of discrepancy on ideological grounds. Churchill explained it in the following words: "In the socialist view the strong should be kept down to level of the weak in order have equal shares for all. How small the share is does not matter so much, in their opinion, so long as it is equal. ... Such a principle is, of course, destructive of all hopes of victory in social and philanthropic advance" (2013: 382).

Churchill's ideology was inspired by the paternalistic one-nation conservatism which dates back to the PM Disraeli in the $19^{\text {th }}$ century. This ideology proposes that the "weak" should receive support from those with higher income but nothing should be done to dismantle the social class divisions. Those up in the social ladder ought to feel the ethical obligation to help but the state should not intervene. In other words, the preservation of social harmony from the "Middle Way Conservativism" could only be achieved by reform

27 The government could designate the areas for the development of new towns by means of this act. The Development Corporation would have the power to regulate it.

28 The Act stated that land development was only authorized if it had a governmental planning permission. 
from above and not from below. It can be claimed that this ideology was far more socially inclusive that the neoliberalist economic ideology from the New Right ${ }^{29}$, but it was still distinct from Socialism.

For Attlee, even distribution of wealth should not only be a mantra of socialism. In 1945, the Labour Party appealed to the electorate in different terms. It should be ensured by the government as a way to acknowledge the efforts of the average citizen during the war. According to this reasoning, if the burden of the war had been shared equally among all, all should equally reap the benefits of the victory ("Let Us Face the Future" 1945: no pages). This egalitarian ethos had been already demonstrated during the war, when, for instance, the $100 \%$ Excess Profit Tax was introduced by the Labour Party with the acquiescence of the rest of the Cabinet. Churchill's and Attlee's manifestos in 1945 and in 1950 both coincided in the need of creating a comprehensive national insurance scheme which would provide "social provision against rainy days" ("Let Us Face the Future" 1945: no pages). This compromise led to the introduction of National Insurance Act of 1946, which included old age pensions of 26 shillings and the National Assistance Act of 1948, which covered the unemployed. The National Insurance Act was passed by the parliament without much hassle. In fact, the Conservatives "failed to oppose either the second or third readings of the Bill", which shows their agreement on this issue (Stewart 2010: 27).

However, controls and rationing was a whole different ballgame. The pledge of the Labour Party was that controls would continue in post-war Britain as a means to ensure opportunities for all. This inevitably meant some sort of state intervention which Churchill was unwilling to accept. Indeed, by 1945, his vague pledge was to scrap controls "to the minimum" ("This is the Road" 1950: no pages). For Attlee, price and rent controls had to be maintained in order to prevent only the rich affording consumable goods and the risk of evictions from homes (1946: 8). Ideological divisions were present here as well, as "anticontrollers", as the Labour Party called them, were accused of "plunder[ing] the rest of the nation ("Let Us Face the Future" 1945: no pages).

\subsubsection{Nationalism}

In no Churchill's speech it is more evident the committed disapproval to socialism than in "Socialism is the Philosophy of Failure" (2013: 372). The Conservative manifestos and speeches always referred to the Labour Party as "socialist" purposefully, although the Labour party was never full-fledged socialist. This was one of Woolton's ${ }^{30}$ electoral strategies. His emphasis on the ideological differences can be observed as a sign of lack of consensus. In the speech, it was expressed the fear of the loss of the great empire status as Socialism was deemed to be destructive to abstract values such as nationalism: "our national independence will be gone" (2013: 372). He also blatantly resisted the creation of "irresponsible employees" (2013: 360) in nationalized industries. His main concern

29 A specific current predominant within the Conservative Party in the 1980 s in favour of full economic liberalism, deregulation and privatization of state-run businesses.

30 Conservative Party Manager, responsible for the change of fortunes of the Conservative Party in the 1950-1 general elections. 
was that they would produce a mass of inefficient, dull and uninspiring workforce, who, without any sort of reward system, would have no initiative to push for further limits in technological process. Only by means of labour flexibility, he stated, the "traditional virtues of the British character [would] be preserved" (2013: 360). This statement is significant, as he subtly linked British identity and patriotism with the willingness of the workforce to accept the ever-changing conditions of the free market. So, a reasonable assessment so far is that there was little consensus between the two political agendas.

The anti-establishment and egalitarian ethos in the 1945 Labour manifesto was a pivotal difference between the two parties. Their concept of patriotism was totally distinctive: it is the economic elite, and not the socialists, who were undutiful to the country. According to them, the rich businessmen and their vested interests "felt no responsibility to the nation" ("Let Us Face the Future" 1945: no pages). Whereas the Labourites' main effort was to raise awareness of the class segregation, the Conservative 1945 manifesto indicated that their main objective was the "unity of the British people, which transcends class differences" ("Winston Churchill's Declaration of Policy to the Electors" 1945: no pages). It is obvious that the target against whom both political parties fought against were divergent and hence little can be said in favour of the idea that there was consensus between them.

\subsubsection{Meritocracy}

Meritocracy was the seal of the Conservative party and one of the elements which must be considered in this discussion. Nowhere it is more evident than in the proposal of The Worker's Charter ${ }^{31}$, where it was stated that "extra effort should always bring extra reward and ... promotion shall be by merit" ("This Is the Road" 1950: no pages). Intimately linked to this concept was the level of taxation. Churchill argued that the income tax was a burden which "discourages the extra effort and superior skill" (2013: 384). High taxes should not be levied as it would provoke a brain drain and an uncompetitive economy. The reduction of the income tax in the Butler 1953 budget was a natural response as a way to cater for the needs of the Conservative electorate, very much in line with their dogmas. Churchill blamed the excessive taxes but he very lucidly did not condemn that the taxes were employed to maintain the NHS or the new social measures. He rather savaged the high costs of the bureaucracy newly created: "in order to pay this and similar and Socialist institutions, oppressive taxes are exacted from all" (2013: 384). According to him, the sufferance of the high taxation rested on the shoulders of the housewives and the working class, emphasizing that consumer goods such as beer and tobacco had been disproportionately taxed (2013:384). This claim was totally right. Beer was taxed seven times higher than before the war (Stewart 2010: 40). But electoral opportunism can be seen here. These items, no matter how high its consumption was, were only commodities. Conservatives really distanced themselves from the taxation scheme of the Labour administration because it was disincentive for the bright minds of the British Empire and this was completely logical according to their principles, but their assertion that the taxation affected all alike can only be understood if we consider it as part of the common political rhetorics of a catch-all party.

31 A section of the Industrial Charter (1947). 
The Labour Party also clearly specified that the taxation should "bear less heavily on the lower income groups" ("Let Us Face the Future" 1945: no pages) in a similar fashion to the Conservatives. Dalton's ${ }^{32}$ social justice consisted of taking some measures to keep their promise in order to protect the worst off. By 1949, taxation was relaxed: the maternity, unemployment and sickness benefits were exempt from it (Thatcher 1966: col. 1896) and three years before, the purchase tax had been eradicated for some household items (Francis 1997: 171). On the whole, Churchill's disagreement with Attlee was mainly about the sharp slope of the progressive taxation.

\subsubsection{Civil Liberty}

Freedom stood by itself as a distinctive sign which separated the Labour and the Conservative Party. Churchill's position directly clashed with the controls and regulations of the Labour government and he considered this as part of the process in which the "machinery for the totalitarian grip upon British society is being built up and perfected" (2013: 371). His critique, when comparing Great Britain with a quasi-Orwellian state, was most plainly seen in the 1945 election broadcast, when he declared that a Labour government would establish a Gestapo-like government (Stewart 2010: 22). For Churchill, Socialism and freedom (the inherent essence of the Britishness) were oxymorons, as "Socialist politicians immediately curtail [freedom] if they are displeased with our [the British] behavior" (2013: 386). Attlee's response was a sustained ideological argument based on the idea that other countries such as New Zealand and Norway had socialist governments "with none of these dreadful consequences. There are no countries in the world more free and democratic" (1946: 7). Attlee, from his ideological standpoint, understood the lack of civil liberty in other terms. He rather put the accent on the freedom of association of trade unions, severely curtailed by the Conservative administration by Trade Disputes and Trade Unions $\operatorname{Ac}^{\mathrm{t33}}$ (1946: 25) and considered that trade unions were the beacon of freedom in a world for the workers who found themselves "enslaved by the economic system" (1946: 106). Attlee and Churchill understood the concept of what totalitarianism meant and what it involved differently and it confirms the lack of consensus.

It is still true that the government control during post-war Britain was arguably higher than in the inter-war period, much to the irritation of the Conservatives. Rationing was one of the clearest examples of these restrictions. The Conservatives' reluctance to endorse this policy showed that the two political parties were far apart in this aspect: "the question ... arises whether there is not some better way of helping the lower income groups ... than ... the whole vast, complex, costly apparatus of rationing" (Churchill 2013: 381). Churchill portrayed himself as the defender of the consumer society of the fifties in contrast with the grey Britain built by Labour party. He summed up his analysis in the following terms: "in peace it [rationing] may well become the alternative to abundance" (2013: 383). Oppositely, the 1950 Labour manifesto reaffirmed the necessity of extending rationing as long as

32 Chancellor of the Exchequer during Attlee's administration (1945-1947).

33 After the General Strike of 1926, Stanley Baldwin (Conservative PM), this Act prohibited strikes, picketing, and prohibited civil servants from joining the Trade Union Congress. 
necessary. It was openly stated that "only by price control and rationing can fair shares of scarce goods be ensured" ("Let Us Win Through Together" 1950: no pages), so the different political outlooks between the two political parties regarding regulations were quite marked.

The implications of Churchill's words must be put in a wider perspective. By that time, clothes and bread were no longer rationed. Even though rationing was reduced at a higher rate during the Conservative administrations, these criticisms can be argued to be exaggerated, playing on the fears of the housewives for electoral benefit. Despite all of this, the rift between the two political parties on this issue was still perceptible because their inherent moral values were different.

Overall, this subsection demonstrates that the lack of theoretical consensus stemmed from their different intellectual backgrounds. Both political parties occupied the middle ground in the political spectrum, but that did not imply that they were sympathetic to the political culture of the opposing political party and that they shared a vision of a common utopian social environment, but quite the opposite.

\subsection{Nationalization and Employment}

Nationalization was an area of disagreement between the Labour and Conservative parties. Here, unlike in other cases, we must differentiate the realm of the words from the one of the government policies. Churchill openly criticized nationalization not because it harmed the big business, but the working class. Ironically, he stated that the employees had more difficulties in bargaining the working conditions with their new government bosses than with the previous private employers (2013: 389). It was also pointed out that nationalization would raise the food prices for the housewives ("This is the Road" 1950: no pages). Again, the appeal of the common British man is a distinctive feature of the one-nation ideology. A historian must not be misled by these harsh words: even though he condemned the nationalization programme, he only brought the steel industry back to the private sphere during his administration. The most logical explanation is that Churchill personally considered that nationalization was inefficient, but he was forced to maintain the status quo due to its popularity. Again, ideological principles contrasted with reality, but disagreement still existed.

The Labour party stressed that the private sector was incapable of achieving full employment and opposed laissez faire. In their 1945 political manifesto the Labourites included a comprehensive list of industries which were "over-ripe for public ownership" ("Let Us Face the Future" 1945: no pages). This clearly makes reference to one of the Marxist premises, that is, the social ownership of the means of production. Hence it is evident the underlying message that nationalization was indispensable in the following years according to the Labour Party. The Conservatives, on the other hand, firmly stated that only through private enterprise "can mass unemployment be averted" ("This Is the Road" 1950: no pages). Attlee's 1945 election broadcast simply treated this economic school of thought in these terms: "it is a pathetic faith resting on no foundation of experience" (1946: 7). This comment is presumably based on the painful experience that the workers underwent in the thirties when unemployment soared. To conclude, Attlee and Churchill polarized on the remedy of unemployment. 
Overall, were there two different political outlooks regarding nationalization? The Labour Party had the impetus to push forward the nationalization even after 1950, when they proposed an extensive programme over less strategic industries such water supply, sugar production, meat, fruit and vegetable trade ("Let Us Win Through Together" 1950: no pages) that would turn the country even more socialist. In contrast, Churchill did not have any intention of continuing the nationalization programme: "we shall bring Nationalisation to a full stop here and now" ("This is the Road" 1950: no pages). Nationalization and employment were contentious issues which reflected the ideological fracture.

\subsection{Education and Welfare: Debunking the Myth of Consensus}

Education, in general terms, was not drastically reformed by any political party. There was an acknowledgement in the 1945 Labour manifesto that the recent Butler's 1944 Education Act was the right step ("Let Us Face the Future" 1945: no pages). It must be remembered that this piece of legislation was approved during the coalition government, so both political parties agreed in this area. Yet, ideology, as always, also marked the differences in terms of their priorities. Ellen Wilkinson wanted to raise the school leaving age to 16 ("Let Us Face the Future" 1945: no pages) as a way to prevent child labour. On the other side of the coin, the Conservatives primary concern was the parental's ability of free choice of the school for their children and the maintenance of grammar schools which were admired by the middle-class and upper-classes ("This Is the Road" 1950: no pages). What was at stake, as in other cases, was an ideological battle: how would young generations access the working world?

The first impression that the reader has when the sources are analysed is that the welfare system was understood by both political parties as something that had to be protected. The Conservatives promised "to maintain and improve the Health Service" ("This Is the Road" 1950: no pages) and Macleod began a new phase of consolidation of the NHS. But there were still subtle differences that must not remain unnoticed. The Conservatives sought the decentralization of the NHS and allowing the family doctor to practice outside his hometown ("This Is the Road" 1950: no pages). This was another way in which the Conservatives aimed to provide more freedom from the restrictive legislation, in agreement with their views.

The Conservatives also proved that they would care for the housing. Harold Macmillan even surpassed all the expectations by building more houses than the Labour government. But this was achieved at the expense of relaxing the previous housing legislation ("the restrictive licensing system as it applies to house building should be removed" ["This Is the Road" 1950: no pages]) and reducing the standards of housing (Stewart 2010: 59). Ideology, even here, permeated all aspects of government. Furthermore, in terms of town planning, the Town and Country Planning Act of 1947 was reviled by the Conservatives because it was not sufficiently flexible and placed too many restrictions in small development plans ("This Is the Road" 1950: no pages). Even though their objectives were analogous, their methods in order to reach the objectives were slightly different. 


\subsection{Economic Management}

Both political manifestos established unemployment as one of the main aims ("This Is the Road" 1950: no pages), yet their economic management differed substantially, as Gaitskell and Butler had two economic rationales. The Conservatives called the Labour economic management the "socialist deception" ("This Is the Road 1950: no pages) and Butler, was, unlike what the myth of "Butskellism" has said, the man who shaped, or at least tried to shape, a completely new vision of the economy. His primary ad hoc response to the inflationary drift in 1952 was that the pound should float, that is, that the exchange rate would be allowed to fluctuate, as a way to counter the negative effects of devaluation and the frequent risk of balance of payment crisis which had happened previously in Attlee's administration. The fact that some members of the Cabinet such as the Chancellor of the Exchequer supported this measure shows that the ideological origins of this new economic rationale (later seen in James Callaghan's ${ }^{34}$ and Thatcher's administrations) were already perceived as early as in the 1950s. The different approaches to running the economy can be considered as disrupting factors of the consensualist thesis.

\section{CONCLUSION}

Bearing in mind what has been discussed so far, there exists sufficient evidence to argue that there was no total consensus between the Conservative and the Labour Party.

The Labour government commenced in 1945 an unprecedented series of changes in the domestic sphere. The fact that the Conservative Party approved the passing of the laws which implemented these reforms has been one way in which historians have proven the existence of consensus. But, politics, as it has been demonstrated throughout this study, is not just a matter of policy making. Politics is also a battle of ideas and moral values. And, in that respect, as it has been seen, Attlee and Churchill could not differ more.

When Churchill won the 1951 general elections, he faced an important constraint. Many British citizens agreed on the political agenda set by Attlee for the next decades. The historical and political construct of a Conservative party eager to follow Attlee's path, as many consensualists argue, falls apart when it is unveiled that Churchill only consented to maintain this new status quo in the name of stability and electoral success. He did not publicly acknowledge to the Conservative electorate that there was no possibility to go back to the pre-war Britain. But his inner convictions and the Conservative creed were incompatible with it. Throughout his speeches and political manifestos, the reader feels this tinge of counter-reform, expressed in strong reproaches against Socialism. They did not take shape in major reforms which would dismantle Attlee's reforms- not at that time. Thus, political consensus seems no more than a myth.

The sources have demonstrated that it was a myth for many reasons. Attlee supported collectivism; Churchill believed in the creation of a property-owning democracy. Attlee assumed that the government was the only entity to rely on for full employment; Churchill

34 Labour PM (1976-1979), responsible for the implementation of deflationary measures which were necessary under the conditions of the IMF (International Monetary Fund) in 1976. 
believed that the private enterprise would be the motor which would generate wealth and employment. Both had different concepts of what "true Britishness" meant. How can we speak of consensus, if they could not agree on such matters?

In effect, Attlee and Churchill envisioned two ways how British society should be structured. Their divergence can all be summarized in one word: ideology. Monetarism and civil liberty were all the underlying themes which the Conservative party essentially put on the table. Even if compromise was reached in some areas, such as the protection of the NHS and the education system, Attlee and Churchill attempted to leave their distinctive ideological mark in their management in these governmental departments and their legislation. Political parties are often influenced by purely possibilist and pragmatic attitudes, but their ideological thrusts explain much of their policies and disagreements. The conclusion to be drawn is that consensus was a mirage: a nostalgic view of those who were too fearful of Thatcher radical measures during the 80s. They purposefully forgot that during the 1940s and 1950s United Kingdom had been the arena of an ideological struggle which would fully surface in the decades to come.

The main contribution of this study of the post-war consensus debate is to underscore the central role of ideology, which other authors have considered to be less significant. However, the scope of analysis of this study is limited, in terms of length (the common historiographical discussion spans for many more years than this study: From the end of World War Two, until the advent of Thatcher, when usually consensualists argue that consensus collapsed) and in terms of the geographical framework. Some recommendations for broadening the breadth of analysis could possibly go along the lines of tracing elements of discrepancy of the two political parties during the previous years of war effort (which have generally assumed to be quite peaceful in the War Cabinet), as a way to demonstrate that consensus was an illusion. Another line of research could contrast the differences between Blatcherism and the Third Way ${ }^{35}$ in opposition to "Butskellism" (if it ever existed) and Attlee's ideology. Finally, the comparison of post-war politics in Britain with those of other countries, specifically New Zealand or those which adopt the Nordic model ${ }^{36}$, might be useful to view this debate in a wider context.

\section{REFERENCES}

ACland, R. 1940. Unser Kampf: Our Struggle. Harmondsworth: Penguin.

AdDison, P. 1975. The Road to 1945: British Politics and the Second World War. London: Cape.

Attlee, C. R. 1946. Purpose and Policy: Selected Speeches. London: Hutchinson \& Co.

35 Political philosophy situated in the centre of the political spectrum, whose main politician in United Kingdom was Tony Blair, PM (1997-2007). Blatcherism is, to some extent, a term applied to the establishment of the Third Way during the nineties as a merge of Thatcher's and Blair's doctrines.

36 The Nordic model refers to the economic and social system in the Scandinavian countries in which a farreaching welfare state, mixed economy and a heavily unionized society is the norm. 
BALOGH, T. 1941. "Work for All.” Picture Post. B. Lake Ed. London; Edinburgh: Morrison \& Gibb Ltd. 10-13.

Blackburn, D. 2017. "Reassessing Britain's 'Post-war Consensus': The Politics of Reason 1945-1979." British Politics 13, 2: 195-214.

Blake, R. 1985. The Decline of Power 1915-1964. London: Granada Publishing.

Brooke, S. 2001. "Gender and Working Class Identity in Britain during the 1950s.” Journal of Social History 34, 4: 773-795.

CAwood, I. 2004. Britain in the Twentieth Century. New York/Oxon: Routledge.

ChurchiLl, W. S. 2013. Never Give In! Winston Churchill's Speeches. London: Bloomsbury Academic.

Francis, M. 1997. Ideas and Policies Under Labour, 1945-1951: Building a New Britain. Manchester: Manchester University Press.

FrY, M. 1941. “The New Britain Must be Planned.” Picture Post. B. Lake Ed. London; Edinburgh: Morrison \& Gibb Ltd. 16-20.

Harrison, B. 1999. "The Rise, Fall and Rise of Political Consensus in Britain Since 1940.” History 84, 274: 301-324.

Kavanagh, D. 1992. "The Postwar Consensus." Twentieth Century British History 3, 2: 175-190.

LeHrer, K. \& WAGNer, C. 1981. Rational Consensus in Science and Society: A Philosophical and Mathematical Study. Dordrecht-Boston-London: D. Reidel Publishing Company.

MARr, A. 2007. A History of Modern Britain. Basingstoke: Macmillan.

Marwick, A. 2003. British Society Since 1945. London: Penguin.

Morgan, K. O. 1990. The People's Peace: British History 1945-1990. Oxford: Oxford University Press.

Murphy, D. 2004. Britain 1914-2000. London: Collins Educational.

Myrdal, A. \& Klein, V. 1956. Women's Two Roles. London: Routledge and Kegan Paul Ltd.

Owen, A. D. K. 1941. “Social Security.” Picture Post. B. Lake Ed. London; Edinburgh: Morrison \& Gibb Ltd. 14-15.

Pimlott, B. 1994. Frustrate Their Knavish Tricks: Writings on Biography, History and Politics. London: HaperCollins.

Pimlott, B., Kavanagh, D. \& Morris, P. 1989. "Is the 'Postwar Consensus' a Myth?" Contemporary Record 2, 6: 12-15.

Pugh, M. 2000. Women and the Women's Movement in Britain, 1914-1999. Basingstoke; London: Macmillan.

Smith, H. L. 1986. War and Social Change: British Society in the Second World War. Manchester: Manchester University Press. 
Stevenson, J. 1991. "The Jerusalem that Failed? The Rebuilding of Post-war Britain." Britain Since 1945. Eds. T. Gourvish \& A. O’Day. Basingstoke; London: Macmillan.

Stewart, G. 2010. British Political History 1945-90: Consensus and Conflict. Harlow: Pearson Education.

Thatcher, M. 1966. "HC S [Budget Resolution and Economic Situation].” Margaret Thatcher Foundation. London. 4 Sept. 2021. https://www.margaretthatcher.org/ document/101481.

Todman, D. 2016. Britain's War: Into Battle 1937-1941. New York: Oxford University Press.

Tomlinson, J. 1997. Democratic Socialism and Economic Policy: The Attlee Years, 1945 1951. Cambridge: Cambridge University Press.

Toye, R. 2013. 'From 'Consensus' to 'Common Ground': The Rhetoric of the Postwar Settlement and its Collapse.” Journal of Contemporary History 48, 1: 3-23.

\section{Institutional Documents}

Great Britain. Conservative Party. 1945. Winston Churchill's Declaration of Policy to the Electors. 15 Jan. 2020. http://www.conservativemanifesto.com/1945/1945conservative-manifesto.shtml.

Great Britain. Conservative Party. 1950. This is the Road: The Conservative and Unionist Party's Policy. 27 Jan. 2020. http://www.conservativemanifesto.com/1950/1950conservative-manifesto.shtml.

Great Britain. Labour Party. 1945. Let Us Face the Future. 15 Jan. 2020. https://web.archive. org/web/20130315015558/http://www.labour-party.org.uk/manifestos/1945/1945labour-manifesto.shtml.

Great Britain. Labour Party. 1950. Let Us Win Through Together. 15 Jan. 2020. https://web.archive.org/web/20120309054242/http://www.labour-party.org.uk/ manifestos/1950/1950-labour-manifesto.shtml.

\section{Churchill's Speeches}

“A Property-Owning Democracy", 5 October 1946. Conservative Party Conference, Blackpool.

"The Rights of The British", 4 October 1947. Conservative Party Conference, Brighton.

"Socialism is the Philosophy of Failure", 28 May 1948. Scottish Unionist Conference, Perth, Scotland.

“Our Socialist Masters”, 9 February 1950. Forum Cinema, Devonport.

“An Experiment in Freedom”, 18 May 1950. Usher Hall, Edinburgh.

"Renewing the Glory of our Island Home" 21 July 1951. Royal Wanstead School, Woodford. 


\section{Attlee's Speeches}

“The Election Broadcast”, 5 th June 1945.

"A Speech to The House of Commons During the Debate on the Address", $16^{\text {th }}$ August 1945.

“A Speech to the Trades Union Congress", 12 $2^{\text {th }}$ September 1945.

"A Speech to The House of Commons on the Second Reading of the National Insurance Bill", $7^{\text {th }}$ February 1946. 